\title{
Two Rivers in Negrodom: Langston Hughes and David Diop
}

\author{
Chiekh Amadou Dieng \\ Cheikh Anta Diop University, Dakar - Senegal
}

An old man from my village told me a story. It was the story of a fourheaded hydra. Four heads, one body. The body is seated on the black man in Africa, in America - North and South - in the Caribbean and in Europe. And the hydra speaks English, French, Portuguese or Spanish. Its tail whacks the yellow man and the red man. So, one day, the black man decides to sooth the beast, but he discovers that it is not an easy job. You see, the hydra has a big family with many children and a ruthless system that works on the body and the mind of the black man. I am not talking about the red man and the yellow man, because they have their own stories. So, one day, the black man turned his tongue seven times in his mouth and said to his kindred: "If we get together, maybe we can do something to redeem our souls and bodies because, you see, this hydra will understand. If it does, fine, if it doesn't, we will still do our thing anyway." That's what the old man told me.

When he finished, I started thinking about Harlem and the Quartier Latin, where many rivers meet. And I saw Langston and I saw David. And they were discussing negritude, the one from the West and the other from Africa, the one speaking English, the other French. And they dreamed their dreams in Paris. That happened one hundred years ago, at the end of their previous lives, when they shared the same age group.

On the hundredth birthday of Langston Hughes, it is quite appropriate to talk about negritude as a concept and a philosophy against a twofold background of slavery and colonisation.

These phenomena, which happened in two totally different topographical entities, namely America and Africa, left undesirable scars on the Negro, even though in different ways, on the surface only. Their object is identifiable by its color and its origin, making it much easier for both slave owners and colonizers to focus on a special brand of man who is bolstered by the contact of his feet with the ground, like Antheus in Greek mythology. ${ }^{1}$ This statement is the landmark, in timelessness, of a movement

${ }^{1}$ Senghor in his poem Prayer to the Masks, wrote about the men "... whose feet regain vigor on touching the firm ground" (Chants d'ombre). 
of self-apprehension that goes beyond boundaries because it posits a new type of Negro who stands up and says,"This is I."2

But first, a few words on the historical peripeteria that lead him to assert so vocally his being here; this means a parallel between slavery and colonialism.

In practical terms, the two processes share in subjugating the victim until he reeks down to the level of a thing or an animal. But slavery is the more pernicious, for many reasons: it takes its object from all his landmarks and deprives him of referents. Where the colonised still has his environmental milieu preserved, along with his language, culture, mores, and family structures, the slave is thingified and kicked away like a ball, depending on the will, whims, and fortunes of his owners. It is quite understandable that he internalizes the subsequent frustrations over his predicament more than the colonised do. As an individual and during slavery, the slave doesn't have the weight of a continent and a community behind him. This makes his existence more precarious because of his loneliness, and the fears that go along with uncertainity and insecurity. The colonised African may never see a white man or know that he has a master, unless he comes from colonial administration centers. Stories about the white man are often jokes out of a distant and unreal world, because there is no contiguity of the two races, whereas the slave is more than a neighbour for the slave owner. They interact all the way through, even when the former is being sold by the latter, or, in extreme cases, shot or lynched by the master's kindred. These differences certainly explain why the selfdeclaration, the movement, and act through which the slave and his descendants express their presence is anterior to and more thunderous than the protest reaction of his brother from Africa. The rehabilitation movement of the Negro was initiated in America, because that is where his plight was the most unhuman and unbearable. The late Pr. Mohamadou Kane goes to the point by indicating that the negritude movement

was, right from the outset, geared toward colonialism . . . At the origin, the real protagonists of the first proponents of Negritude were less the subjugated African peoples than the peoples of Europe who were responsible for these inequities .. . ${ }^{3}$ Mohamadou Kane 1971: ${ }^{3}$

We take here the liberty of extending Europe to white America and linking colonialism to the "peculiar system" experienced by Negroes in that

\footnotetext{
${ }^{2}$ Cf. William Shakespeare's Hamlet: "This is I, Hamlet the Dane" (Hamlet, $\mathrm{V}, 1,1238$ ).

${ }^{3}$ Mohamadou Kane, in "Colloque Spécial sur la Négritude," proceedings, published by le Soleil, special issue, Dakar, 8 Mai 1971, p. 21.
} 
country. In so doing, we can easily see how negritude encompasses the ideas of Frederick Douglass, Marcus Garvey, William Edward Burghardt $\mathrm{Du}$ Bois and the movement called the Harlem Renaissance, in which Langston Hughes was a leading figure. In the poems, plays, and other literary expressions of the negritude movement, we can find all the paraphernalia of the Harlem Renaissance. But let's begin with the concept itself, with its philosophy and meaning. Many definitions have been given, each tinged with the personal experience and itinerary of its author. We will choose Césaire, Senghor, and Hughes, but before them, Blyden and Garvey, even though these two do not partake in the modern conceptual process as a collective enterprise.

Blyden talked about the "African personality" during a lecture he gave in Freetown, Sierra Leone, in 1893 summarized by Irele as a "foundation, in the African culture and civilisation, of the collective personality of blacks the world over". ${ }^{4}$ The implication is a recognition of the existence of a common destiny for all blacks, and subsequently, of the necessity of selfassertion on the basis of this recognition. George Shepperson writes that Blyden recognized the necessity of Pan-Africanism to "bolster both NegroAmerican and emergent African nationalist self-esteem." ${ }^{5}$

Marcus Mosiah Garvey's Universal Negro Improvement Association is, with its own designation, telling enough in this regard. Garvey puts the race first and wants to build a pan-Negro movement on the basis of the most obvious thing blacks have in common: their blackness, which is intrinsically linked to their history. Garvey asserts, "The Universal Negro Improvement Association advocates the unity and blending of all Negroes into one strong, healthy race." ${ }^{66}$

Blyden and Garvey can be seen as precursors insofar as their personal ideas will be used later in structured collective movements such as negritude.

Aimé Césaire, the inventor of the word, defines "negritude" as follows: "Negritude is the mere recognition of the fact of being black and the acceptance of this fact, of our destiny as Blacks, of our history and our culture." 7

${ }^{4}$ See Abiola Irele, "Negritude et African Personality," Ibid, p. 35.

${ }^{5}$ George Shepperson in Melvin Drimmer, ed., Black History: A Reappraisal. Garden City, NY: Doubleday, 1968, p. 506.

${ }^{6}{ }^{6}$ Garvey in Negro World, April 28, 1923. Quoted also by Tony Martin in Race First, Westport, CN: Greenwood Press, 1976, p. 37.

See also Garvey in Amy Jacques-Garvey, ed., Philosophy and Opinions of Marcus Garvey, Atheneum, New York, Atheneum, 1986, Vol. I, p. 102, for the development of the same idea in a closing note.

${ }^{77}$ L.S. Senghor, "Problématique de la Négritude," in Colloque Spécial sur la Négritude, op. cit, p. 5, quoting Césaire. 
This definition aligns with what Senghor himself says when determining the tasks of negritude:

\begin{abstract}
Assuming the values of the civilization of the black world, actualizing and enriching them, if needs be, with external contributions, in order to live them out by and for oneself, but also to make them through and for the others, bringing, in this way, the contribution of the Negroes to the Civilization of the Universal. ${ }^{8}$
\end{abstract}

This bridges the gap between the artificial division based in topography and language, which has been at the core of many squabbles between Francophones and Anglophones, between continental Africans and Negroes from the diaspora, between the great ideals of the Harlem Renaissance, African personality, and the biased perception that tries to limit negritude to the Francophone world. ${ }^{9}$ We can say then that negritude is not an offshoot of the Harlem Renaissance but something bigger that encompasses Harlem in its turbulent years, even though chronologically it took place later. Harlem was a seed for negritude.

The racial consciousness developed by both movements expresses itself in a way that affirms pride and asserts an ego. This is seen by some as a reverse racism, but its foundations lie in the fact that the Negro is obliged to fend for himself in America and elsewhere, and the racial dimension of this new consciousness extends to the crucial field of self-perception, which defines and bolsters attitudes and behavior. The whole literary production of the Harlem Renaissance, of the earlier poets, playwrights, and artists in the intellectual circles of the Quartier Latin in Paris, shares in transcending the barriers of topography, language, and religion to level up together and grow through, for, and by the common element blacks have: their Negroness, which they carry as an indelible mark.

I will use a comparative approach to the poems of Hughes and David Diop, ${ }^{10}$ two poets separated by nationality, language, and generation, to support the above statements.

\footnotetext{
${ }^{8}$ Ibid.

${ }^{9}$ Senghor's argument for the choice of a French word is based on the fact that it has both the concrete and abstract meanings of the Latin word "nigritudo," that is "the fact of being black, the color black, blackness." $\mathrm{He}$ also indicates the existence of the word "Nigritude" in the Harraps but makes the remark that the latter has a concrete meaning which is overruled by the wider sense of the French, which "shifts" from the concrete to the abstract, from the material to the spiritual" Ibid ${ }^{10}{ }^{10}$ David Diop, poet from Senegal, was born in 1927 in Bordeaux, France, when Hughes was 25. He died in 1960, seven years before Hughes.
} 
Hughes and Diop share first a common heritage. But it doesn't stop there: they react to it in a similar way through their poetry. They both use sarcasm to escape the demeaning image white racists try to impose on them:

\section{Diop}

You are just a negro

A Negro

A dirty negro

\section{Hughes}

I am a Negro

Black as the night is Black

Black like the depths of my Africa ...

Your heart is a sponge that soaks up I brushed the boots of Washington ...

That frantically soaks up

I've been a victim

the poisoned liquid of Vice

The Belgians cut off my hands in

And your color locks up your blood the Congo

In the eternity of slavery

They lynch me still in Mississippi

I am a Negro ${ }^{11}$

Their two poems say the same thing from two different perspectives: Diop laughs away in direct speech the scornful image of his own self, built and conveyed by the white racist. The title of this poem is "A White Man Told Me," where Hughes builds on self-perception to express self-acceptance and pride. Diop implies, in front of the white man, "I am not what you want to tell me that I am" Hughes asserts "I am what I am." They are both Negroes and proud of the fact.

The Negro is always related to Africa. Distance and absence won't affect the mind of the black when it comes to a sense of identity and origin. To the first three verses of Hughes' poem, we can juxtapose Diop's lines:

Africa, my Africa

I have never known you

But my eyes are full of your blood

Your fine black blood scattered around the fields. ${ }^{12}$

The love for the race leads the two poets to a denunciation of fake identities, lies, and cosmetic faces.

\footnotetext{
${ }^{11}$ Diop, "Un Blanc m'a dit" (our translation). Hughes, "Negro."

${ }^{12}$ Diop, "Afrique"
} 


\section{Diop}

Brother whose teeth glitter upon

Hypocritical compliments

Brother with the gold-rimmed glasses

Upon your eyes turned blue by the word

Of the master

My poor brother in your silk-cuffed smoking

Whining and whispering and swaggering in the saloons of condescension

We pity you

Now the sun of your land is no more than a shadow

On your civilized forehead ...

\section{Hughes}

You sicken me with lies, With truthful lies

And with you pious faces.

And your wide, outstretched, mock-welcome, Christian hands, While Underneath

Is dirt and ugliness, And rottening hearts, And wild hyenas howling In your soul's waste lands ${ }^{13}$

The "Renegades" are just like "Certain Brothers" in their painted appearances, superficial manners, and alienated hearts. It is quite normal that they be denounced and rebuked, not in their "selves," but their attitudes, which are a denial or even a stark rejection of their Negroness. There is no difference between the Uncle Tom and the self-conceited and brainwashed Negro who jives frantically on the fringes of white saloons in Europe.

The Negro whose life is built on what Hughes call the "racial mountain" is another brand. The trumpet player

... Has dark moons of weariness

Beneath his eyes

Where the smoldering memory

Of slave ships

Blazed the crack of whips

About his thighs ..."

\footnotetext{
${ }^{13}{ }^{13}$ Diop: "le Renegat" (The Renegade). Hughes: To Certain "Brothers." We can add also Hughes' "Uncle Tom" with his "Beaten pride," his obsequious/double bow/ The sly and servile grace/ of one the white folks/long ago/Taught well / To know his / Place"
} 
This is echoed miles away and years later by Diop's

"My memory suffers

Like the plant torn out of the maternal breast.

And the blood of my years of exile

The blood they thought dry in the casket of words

Regains the fervor that runs through mists." ${ }^{14}$

The power of the music produced by the trumpet player is duplicated in Diop's "Negro protest from Africa to the Americas," tying again all Blacks together in the same mold of destiny.

On more political grounds, Diop and Hughes can offer offer a revolutionary, or at least a militant, approach to the issue of social structure and status of the human being in the labor context. They side with the exploited masses and express an undaunted hope in the inevitable changes to come. Artistically speaking, their stands reflect deep trust and a strong conviction that the peoples who have been victims of colonialism and slavery will stand upright and regain their freedom and dignity.

The turpitude of history has tried to bend down the Negro. In their accounts, the two poets have a class approach that certainly, to conform to the realities of history, puts at the forefront negrodom but broods wider to include all the exploited masses, all "minus habendi" of the world. It smacks of a Marxist denunciation. For example, Hughes crafts open and straightforward references to "Comrade Lenin of Russia"; "Revolution," which will allow us to "take everything"; Robespierre, who screams "ça ira. ça ira! ça Ira!," to say that changes are on the way_radical ones at that. The mobilization knows no frontiers. ${ }^{15}$

Lenin walks around the world.

Frontiers cannot bar him.

Neither barbed wire scar him. ${ }^{16}$

This romantic but sincere presentation of a realistic dream embodies the expectations of the proletariat. Diop moves on the same track to warn the establishment and the perpetrators of physical and mental violence that change is imminent, and will be achieved by any means necessary. The upheaval is one of all the "wretched of the Earth," to use Frantz Fanon's phrase. Diop's powerful words hammer into his reader's ears the moanings

\footnotetext{
${ }^{14}$ Hughes, "Trumpet Player," Diop, "Listen, Comrades."

${ }^{15}{ }^{15}$ See Hughes, respectively, "Ballads of Lenin," "Good Morning

Revolution," and "Final Call."

${ }^{16}$ Ibid "Lenin"
} 
of a lumpen proletariat and a compact mass of desperate but resolute men mobilizing for freedom. As in Hughes' poems, they know no frontiers:

\section{WAVES}

The furious waves of freedom

Slap and Slap the bewildered Beast

A fighter has been born out of the former slave

The docker in Suez and the coolie from Hanoï

All those intoxicated with fatality

Started their loud song in the midst of the waves

The furious waves of freedom

Which slap and slap the bewildered Beast. ${ }^{17}$

The inexorability of a new era is bellowed out of this visualized image of mighty nature.

The world to come is one of drastic change, and the road will be rough. The labour that precedes birth is inevitable:

I say the virile storms

Will crash the patience mongers. ${ }^{18}$

This prophecy is possible because, on both sides of the Atlantic, the "Freedom Train" in Alabama and Mississippi also links the Congo to West Africa, and whistles after the death of Mamba and the sevens of Martinsville. ${ }^{19}$ The pariahs refuse to bend their backs any longer, thus creating conditions for confrontation. If Hughes is vocal in his choice of role models here, Diop turns vociferous, but in a cold, almost ethereal, admonition:

You bending you moaning

You dying perchance some day, without knowing why

You struggling, watching the Other's rest

You looking the laugh of your eyes gone

You, brother with a face of fear and anxiety

Stand-up and shout : NO! ${ }^{20}$

${ }^{17}$ Diop, "Les Vagues"

${ }^{18}$ Diop, "Certitude"

${ }^{19}$ Hughes, "The Freedom Train" and Diop, "Ecoutez, Camarades"

${ }^{20}$ Diop, "Défi à la force" 
The injunction is clear here, and we find the accents of Aimé Césaire drilling the hearts of negrodom :

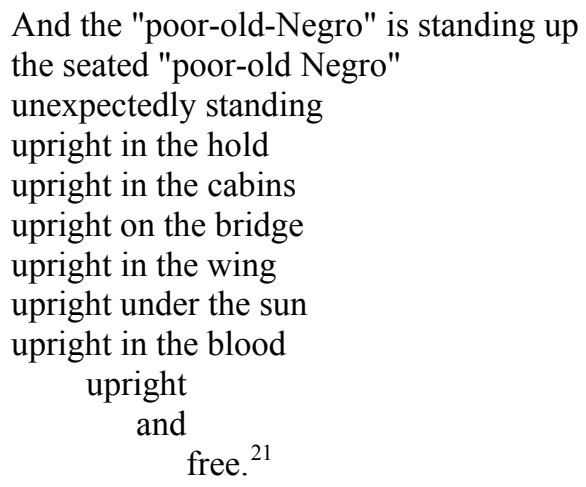

When their two rivers meet, Hughes and Diop reach a point beyond lament and complaint. They preempt the future of the black without complacency. Their poetry is both a movement of self-retrospection and a projection into an optimistic vision of tomorrow, whether through laughter, love, necessary violent changes, but all on a foundation of humanism, the humanism of negritude. 